\title{
САВРЕМЕНОСТ И СВЕВРЕМЕНОСТ У НАУЦИ О ЈЕЗИКУ И КЊИЖЕВНОСТИ
}

(Савремени токови у науци о језику и книжевности, тематски зборник радова, књига 2, ур. Марина Јањић, Филозофски факултет Универзитета у Нишу, 2019)

Осми по реду научни скуп под називом Наука и савремени универзитет 8 одржан је на Филозофском факултету у Нишу 10. новембра 2018. године. Зборник реферата представљених на скупу објављен је годину дана касније у издању Филозофског факултета у Нишу, и то у две књиге. У првој књизи, која носи назив Савремено друштво и наука, нашла су се 23 рада из области филозофије, психологије, социјалне политике, социјалног рада, педагогије и историје. Друга књига (Савремени токови у науции о језику и кюижевности), предмет овог приказа, доноси 32 рада на српском, македонском, француском и руском језику, распоређена у 6 одељака: Вуков Српски рјечник из 1818. у науци о језику и књижевности - 200 година касније (4 рада); Савремени токови у науци о књижевности (10 радова); Савремени токови у науци о језику (5 радова); Нове тенденције у настави језика (5 радова); Романистика и словенски језици, књижевности и културе у контакту и дисконтакту (2 рада); Савремена лингвистичка, књижевна и методичка истраживања у области русистике (6 радова).

Зборник почиње радом „Појава и моћ Вуковог Рјечника из 1818. у оцјенама знаменитих књижевника и лингвиста” Миодрага Јовановића, који за предмет има вредновање лексикографског рада и реформаторских идеја Вука Стефановића Караџића у делима Александра Белића, Павла Ивића и Ива Андрића, пре свега. У раду се такође дискутује о позитивним и негативним реакцијама Вукових савременика на појаву Српског рјечника из 1818. године.

Рад Кристине Митић под насловом „Српска средњовјековна прошлост у Вуковом првом Рјечнику” бави се откривањем присуства српске средњовековне прошлости у поменутом лексикону. Неколико де- 
сетина одредница показује да је Вук „вратио сјај српској култури и преко Рјечника упознао заинтересоване Европљане са нашим старим споменицима и споменарима" (24). О српској прошлости сведоче одреднице типа Вилиндар, Задужбина, Бановић Страхиға, као и коментари уз Краљище, Лазарице и др.

Желећи да осветли језичку слику жене у Вуковом времену, Јелена Стошић је спровела семантичку и творбену анализу око 400 лексема којима се именује женска особа у првом издању Српског рјечника („Лексеме које именују женску особу у Вуковом Сриском рјечнику (1818)"). Ексцерпиране лексеме распоређене су у 4 семантичке категорије: етници и регионална имена, вршилац радње, носилац особине и именовање жене према мужу. Анализа грађе је указала на то да је у творби ових лексема најзаступљенија суфиксација.

У средишту рада „Концепт гостопримства у језичком сазнању српског народа (на примерима из Вукове грађе)” Тање Милосављевић јесте „анализа језичке репрезентације и семантичке интерпретације концепта гостопримство на српској језичкој слици света, истраживањем модела концептуализације овог социо-културног феномена у језичком сазнању Срба и издвајањем лингвокултурних карактеристика датог концепта" (45), извршена на грађи узетој из дијалекатских речника и речника стандардног језика, те Вукових Народних пословища (1836).

Слободан Селинић у раду „Књижевна сарадња Југославије и Источне Европе у извештајима југословенских писаца шездесетих и седамдесетих година 20. века" проучава извештаје југословенских писаца (Ч. Миндеровић, Б. Петровић, Д. Јеремић и др.) који су у наведеном периоду боравили у Пољској, Мађарској, Источној Немачкој, Чехословачкој, Румунији и СССР-у, будући да се ради о корисним историјским изворима.

У студији „Чекање и чежња у теорији Ролана Барта, филозофији Михаила Епштејна и поезији Десанке Максимовић” Снежане Калинић пореде се теорије о љубавним дискурсима изнете у еротолошким студијама Ролана Барта (Фрагменти туббавног говора) и Михаила Епштејна (Филозофија тела), које се потом доводе у везу са раном љубавном лириком Десанке Максимовић. Дошло се до закључка да су у анализираним делима начини на које се чекање повезује са чежњом, стрепњом и жељом у љубавним односима различити.

Милица Иносављевић Вучетић у прилогу „Примена теорије полисистема Итамара Евен-Зохара при одређивању положаја шпанске преводне књижевности у оквиру југословенског система 30-их година XX века", полазећи од друштвене детерминисаности текста као кључног постулата теорије полисистема, настоји да објасни „како и зашто је опште 
погоршање политичких, економских и културних прилика у свету у датом периоду утицало на пролиферацију шпанске преводне књижевности у оквиру тадашњег југословенског књижевног система” (88).

Тања Цветковић се у раду „Архетипски симбол беле богиње у песмама Роберта Гревса и Маје Херман Секулић” фокусира на тумачење уводне песме у књизи Бела богиға Роберта Гревса и дуге песме Госпа од Винче Маје Херман Секулић, као и појединих романа Маргарет Атвуд, ослањајући се првенствено на виђење Нортропа Фраја као зачетника архетипске критике.

Биљана Солеша текст „Симболика простора у прози Лазе К. Лазаревића" посвећује просторним односима са функцијом карактеризације ликова и приказа њихових душевних стања. Након прегледа ставова релевантних аутора о простору у прозним делима, пажња се усмерава на симболику неме сцене у приповеци Први пут с оцем на јутрене и ентеријер и ванпросторне односе у приповеци Све ће то народ позлатити.

У раду Јелене Алексов под називом „Нови историзам у анализи приповедака Симе Жикића” је применом приступа новог историзма у анализи збирке приповедака Пархојске слике и прилике указано на „различита преплитања уметничког, друштвеног и историјског, а самим тиме и повезаности тематике дела са дискурсом прошлости” (119).

Рад „Домановићев хумор из угла когнитивистичких теорија” Оливере Марковић сагледава хумор у приповеци Данга из перспективе концептуалног сажимања, когнитивне наратологије и теорије могућих светова. Два су проблема у средишту пажње овог рада: структуралнофункционалистички аспект појединачне шале и функционисање конкретне шале у оквиру текста.

У циљу сагледавања настајања десетотомне саге Дивљи вепар Данијела Вујисић се у раду „Дивљи вепар Живојина Павловића - књижевна генеза и хронолошко-структурна мапа циклуса” бави истраживањем трију књига Павловићевих дневничких записа, које садрже значајна сведочанства о „амбициозном стваралачком подухвату” (147), поредећи притом пројектовано и реализовано.

Сузана Бунчић у студији „Интертекстуални поступци у Англоcy М. Капора” прати интертекстуалне поступке у поменутом роману и закључује да је Капор употребом цитата, алузија и сл. тежио „или обнављању, синтетизовању и чувању књижевног и културног памћења или њиховом разлагању, пародирању и травестирању” (157-159).

Текст Милана Громовића под називом „Дискурс молитве у поезији и есејистици Слободана Костића" доноси анализу дискурса молитве у есејистичком огледу Православно духовно песништво и у књигама поезије Жилиште, Читање мапе и Покајничке песме. Истакнуто је да је 
Костић у поменутим делима осликао „својеврсну генезу молитве као мотива, формалног и садржинског предлошка у српском савременом песништву" (169).

Интересовање је у раду „О придевима са значењем сличности са творбеног и семантичког аспекта” Биљане Васић усмерено на придеве са значењем сличности као језичком средству за изражавање семантичке категорије компаративности. Показало се да је у формирању значења сличности улога семантичке деривације значајнија од оне коју имају творбени процеси.

Рад „Романизми у Црнотравском речнику Радосава Стојановића: семантичка адаптација" Јоване Стевановић базира се на испитивању значења позајмљеница у говору Црне Траве у поређењу са стандардним српским језиком. Анализом материјала је установљена учесталост потпуног поклапања значења реплике и модела и сужења значења реплике у односу на модел, али и реткост проширења значења реплике у односу на модел.

Нина Милановић у студији „Фигуре мисли у роману Р. Ц. Неминовно (нова верзија) В. Матијевића" из наратолошке и лингвостилистичке перспективе сагледава иронијско, иронично и фантастично у поменутом роману. Утврђено је да наведена обележја проистичу из неподударања фразеолошких и идеолошких тачака гледишта лика, приповедача и читаоца, односно употребе хиперболе као доминантне фигуре мисли.

Коауторски рад Марине Спасовске и Марине Даниловске „За некои правописни решенија во македонскиот и во српскиот јазик" доноси компаративну анализу најновијих издања правописа македонског и српског језика. Рад скреће пажњу на употребу великог слова, састављено и растављено писање речи и скраћенице.

Компаративна анализа семантичких ознака и синтаксичких примена узвика bre / бре, извршена на оригиналном тексту романа Д. Сотироу Земља натопљена крвљу и његовом преводу на српски језик, довела је Панајотиса Асимопулоса, аутора рада „Конвергентни и дивергентни параметри семантичке и синтаксичке функције узвика „bre” / „бре” у caвременом грчком и српском језику", на закључак о изненађујућој подударности у употреби наведеног узвика.

У раду „DSD-Schulen пројекат и настава немачког језика у образовном систему Републике Србије” Ане Ђорђевић даје се опис језичке образовне политике Савезне Републике Немачке и Републике Србије, као и опис пројекта Deutsches Sprachdiplom (DSD), и то на примеру наставе немачког језика у Првој нишкој гимназији „Стеван Сремац”.

Примена нових технологија на часовима књижевности тема је 
рада Милене Каличанин („Употреба нових технологија у настави књижевности: пример англосаксонског епа Беовулф"). Највећи део студије усмерен је на праћење епа Беовулф од усмене херојске поезије, преко његове писане верзије, па све до разних модерних варијаната (филмске адаптације и сл.).

Марина Даниловска и Марина Спасовска у кратком прилогу „Развивање на критичкото мислење кај учениците на часовите по мајчин јазик” разматрају могућност развијања критичког мишљења ученика на часовима македонског језика и књижевности, наглашавајући да оно умногоме зависи од наставниковог умећа да ученике подстакне на активно слушање, дискусије, интеракцију и сл.

Студија „Телевизијске рекламе у настави шпанског као страног језика" Соње Пајић заснива се на анализи употребе телевизијских реклама као дидактичког средства у настави шпанског језика. Проверавају се ставови професора шпанског језика према рекламама као средству које може допринети „развијању продуктивних и рецептивних језичких вештина и комуникативне компетенције” (287).

Љубиша Митровић у раду „Маргиналије на тему дигитализација, хуманизација и еманципација” испитује „однос процеса дигитализације и демократизације у савремености" (291). Размотривши место и улогу друштвено-хуманистичких наука у савременом свету, аутор указује на неопходност њихове демаргинализације.

Ирина Бабамова и Снежана Петрова („Perception et réaction à l'égard de la langue française au sein dy système éducatif macédonien”) најпре пружају историјски преглед стања у вези са перцепцијом и присуством француског језика у Македонији, а потом указују на узроке његове данашње неповољне позиције, и то из угла ученика и студената, родитеља ученика и професора француског језика.

Нермин Вучељ у раду „Les texts littéraires dans les manuels serbes du FLE pour les écoles primaries dans la période 1963-2007” анализира књижевне текстове који се појављују у уџбеницима за француски језик намењеним ученицима старијих разреда основне школе. Испитује се избор књижевних текстова, њихов жанр, као и контекст учења у којем се примењују.

Дејан Марковић се у раду „Речевое поведение учителя на урока русского языка на начальном этапе в сербской аудитории” бави говорним понашањем наставника на часовима руског језика на почетном нивоу, предочавајући истовремено различите тенденције коришћења страног језика у говору наставника.

Студија Велимира Илића „Право у руској књижевности XIX и XX века: књижевни текст у настави страног језика” настала је као „ре- 
зултат истраживања могућности конципирања уџбеника руског језика за студенте правног факултета, који би се заснивао на текстовима из руске књижевности, првенствено правне тематике" (349). Издвојивши корпус одговарајућих књижевних текстова, аутор сагледава методичку оправданост њихове употребе на курсевима језика.

На основу грађе из романа Анна Каренина и његовог превода на српски језик, Весна Мићић у прилогу „Соматизам очи као локализатор емоција у руском и српском језику” пореди предлошко-падежне конструкције са соматизмом очи као локализатором емоција. Анализом је потврђено и постојање алтернативних начина за изражавање локализације емоција уз локализатор очи.

Емилија Јовић радом „Лингвистички и културолошки аспект описивања историзама (на плану руског и српског језика)" сагледава историзме као лексиколошки и културолошки феномен, и то на корпусу сачињеном од историјских романа А. Толстоја и њихових превода на српски језик. У раду се такође указује на могућност примене историзама у превођењу и у настави руског језика као страног.

Јелена Лепојевић у прилогу „Синонимија супстантивата са дериватима и придевско-именичким синтагмама (на материјалу руског и српског језика)" проучава супстантивате који имају деривате образоване на основама истих придева као семантичке парњаке. Показало се да супстантивати и суфиксални деривати могу бити у односу потпуне или делимичне синонимије, али и потпуног семантичког разграничења.

Рад „Два руска глагола быть и њихови српски еквиваленти (На материјалу Толстојевог романа «Воскресение»)" Маје Вељковић, последњи у зборнику, пружа конфронтативну анализу глагола быть, који у руском језику може бити пунозначни и копулативни глагол, и његових српских еквивалената.

Будући да аутори из земље и региона у својим студијама отварају и решавају низ разноврсних проблема из домена србистике, романистике, русистике и наставе језика, јасно је да се значај овог тематског зборника, али и традиционалног нишког научног скупа уопште, не може занемарити.

\section{Александра М. Антић \\ Универзитет у Нишу \\ Филозофски факултет ${ }^{1}$ \\ Департман за србистику aleksandraantic1993@gmail.com}

1 Рад је финансијски подржало Министарство просвете, науке и технолошког развоја Републике Србије. 